\title{
The Revival of Psychological Anthropology: \\ a New Understanding of Interrelation Between Cultural and Psychological By Virtue of Cognitive Anthropology and Cultural Psychology
}

\author{
Svetlana V. Lourie* \\ The Sociological Institute of the RAS \\ 25/14, 7th Krasnoyarmeyskaya Str., \\ St. Petersburg, 190005, Russia
}

Received 18.10.2016, received in revised form 03.07.2017, accepted 13.07.2017

The article deals with the history of psychological anthropology revival during the 80-s-90-s of the $X X$ century after the period of its decline. Psychological anthropology could no longer be regarded as a fully-fledged part of cultural anthropology in the 60-s of the XX century. The interrelationship between cultural and psychological was called into question. It needed to be reconsidered. A new understanding of this interrelationship was given by cognitive anthropology, which emerged as a result of the cognitive sciences development, and cultural psychology, which based on psychology of Lev Vygotsky and other representatives of the "activity approach". The article considers various aspects of mutual interference of cognitive anthropology, cultural psychology and psychological anthropology as well as new issues that psychological anthropology is facing now.

Keywords: psychological anthropology, cognitive anthropology, cultural psychology, cognitive sciences, systems of cultural values, cognitions, emotions.

DOI: 10.17516/1997-1370-0106.

Research area: theory and history of culture.

By the early 60-s of the XX century psychological anthropology seemed to wander into a blind alley after a period of rapid development associated with the names of Ruth Benedict, Margaret Mead, Alfred Kreber, Claude Clachan, Roheim Geza, Abram Kardiner, Cora DuBois, Anthony Wallace, Jeffrey Gorera, Alex Inkeles, Daniel Levinson, George Wood, Weston La Barre, Florence Kluckhon, Fred Strodbeck, Irvin Child, John Whiting, David
McClelland, Francis Hsu, Ralph Linton, John Honigman, Victor Barnow, et al. For decades anthropologists suggested many versions to explain the interrelation between culture and psychology, and all these versions were rejected one after another. After that a point of view about the absence of any interrelation was established for a quarter of a century, since, as it was recognized at that time, psychology has no direct effect on functioning of culture, just

(C) Siberian Federal University. All rights reserved

* Corresponding author E-mail address: svlourie@gmail.com 
as culture has no direct effect on the formation and functioning of human psyche and culturalpsychological processes are nothing more than a phantom. There seemed to be no research field for psychological anthropology.

Meanwhile, since cultural anthropology studies the functioning of culture, the issue ultimately boiled down to the definition of the concept of culture. Most anthropologists of the late 60 -s - early 80 -s considered culture as a system of meanings (signs, symbols) representing a complex and "dense" linking. The natives, their words, dialogues, actions, and interactions are also regarded as meanings (signs, symbols). Obviously, it was assumed that people think of something and respond to the outside world somehow. Yet, these were not recognized as the phenomena directly related to culture. It was believed, to understand the culture it is quite enough to know about the explicit human manifestation, or visible actions and statements of people who were subject to anthropological interpretation. The thoughts people think, the emotions they feel, the emotional states they are in, the things they hold back (and why) and mean by making this or that statement, the things they are aware of (and those that they are unconscious of), true motivation of people's behavior were considered a subject of psychology, which should not be the scope of interest for the anthropologists. This approach was obviously limited but internally consistent. It was impossible to be simply turned down, it had to be overcome. Hence, the first issue for psychological anthropology is to prove the inextricable interdependence of culture and psychology.

With no regard to post-modernist criticism, which was more of a journalism, fiction, but not science as it did not sought to create a holistic theory but made do with a set of principles of humanitarian or even political content, cultural anthropology in its theoretical part would split up into two areas: symbolic anthropology and cognitive anthropology. The former studied culture as a system of meanings with no interest in how these meanings are reflected in the individuals' minds, thus putting an impermeable barrier between culture and psychology and refusing to consider any of psychological manifestations within the science field of anthropology. Thus, it was assumed that psychology does not show the slightest interest in anthropological research.

Cognitive anthropology also studied the system of meanings not in the objectified cultural field but in the individual's mental space. This science had the strongest connection with psychology, or, more precisely, with a cognitive cycle of sub-disciplines within the scope of psychology, these disciplines being the theories of perception, thought, memory. However, until the right time, the study of an individual's ideas of culture promoted no step forward for the researchers to explain the nature of the phenomenon of culture. It was necessary to somehow integrate the researches of meanings in culture, which are independent of an individual's mental activity, and meanings in the mental plane, to find a correlation between them, otherwise, both leading trends in cultural anthropology ran into a blind alley the same way psychological anthropology did. There was a threat for cognitive anthropology to merge with cognitive psychology, and for symbolic anthropology to turn into semiotic hermeneutics. Once again the researchers were confronted with a question of need of a science to study both the objective cultural meanings and mental meanings, the mental meanings related to objective culture but not cultural meanings as having psychological causes and effects. Here comes the turn of psychological anthropology. 
Psychological anthropologists of that time made Herculean efforts to tear down the wall of misunderstanding and interest psychologists with their research. It should be noted that at that time psychology itself was in acute crisis. Irrespective of anthropology, while searching for the way out, it turned to seemingly peripheral fields of psychology, which initially considered that culture, like biology, is a source of psychological. This trend resulted in the formation of cultural psychology that was considered an integral part of psychological anthropology from the 80 -s.

\section{$* * *$}

If in 1978 they published a book that seemed to sum up the final results of psychological anthropology development (Spindler, 1978), in 1984 there appears a collection of works which can be considered a forerunner of modern psychological anthropology (Shweder, LeVine, 1984). It no longer raises the question of an integrated research of culture and psychology with the same confidence. The task is much more minimalistic. It is in finding of points of cultural and psychological correlation, in establishing certain relationships with accuracy. The collection comprised the works by all leading anthropologists of that period, regardless of their subject area. It is not a collection representing a current research area but a collection initiating the discussion in which some articles aim to disprove the others. Clifford Geertz, the leading researcher of symbolic anthropology, tries to deny all approaches attributing psychological components to cultural meanings (Geertz, 1984). His opponents are divided into two parties some of them agree that cultural meanings in themselves do not have psychological components but excite them in an individual; the others believe that cultural meanings have motivational and emotional components. In any case there is a kind of dualism: there is a parallel coexistence of culture and a mental field with their relevant systems. To avoid the confusion in terminology D'Andrade suggests that the former should be termed as symbols. A new objective of psychological anthropology is clear, the objective being the establishment of the relationship between the objectified reality and mental reality.

The task would seem too simple but for the generations of anthropologists and dozens of theories which failed to clearly and convincingly demonstrate what that interrelation is. That was the revival of psychological anthropology. In 1992 a weighty volume of "New Directions in Psychological Anthropology" (Schwartz, White, Lutz, 1992) was published. In 1994 "The Handbook of Psychological Anthropology" (Bock, 1994) was published. Both publications were generally aimed to define the approaches to the tasks mentioned above.

The matter does not concern putting forward a single leading approach (that is the formation of a scientific school) yet. Psychological anthropology is a set of various conceptions with a common research objective which is more implicit than explicit. Thus, psychological anthropology covers a very wide field of research. Moreover, it integrates a number of disciplines that have been considered as autonomous ones. For the first time these editions contain cognitive anthropology, cultural psychology, cross-cultural studies as parts of psychological anthropology.

$$
* * *
$$

During the period of its revival in the 80-s psychological anthropology existed in a different context than the science the successor of which it was and the name of which it still had. Psychological anthropologists had already no possibility to happily claim that their objective is an integrated study of culture and psychology. And although at heart many of them still saw their 
objective the way their predecessors did it was necessary to explain their aims in the language of their epoch, when many scientific paradigms had already replaced each other. This language was a language of a mature modern science, which never puts forward disputable statements as scientific assumptions. First of all it was necessary to prove that psychological and cultural phenomena do not lie in completely different planes but have common features. This was stated in the works by Theodore Schwartz, Geoffrey White, Milford Spiro, Robert LeVine, Roy D’Andrade, Richard Schweder, Gustav Jahoda, Philip Bock, Catherine Lutz, Sara Harkness, Harry Triandis, et al.

The fact that there is no culture, separated by an impenetrable wall from psychology, and there is no psychology, separated by an impenetrable wall from culture is obvious from the point of view of common sense. Yet, common sense is far from being a scientific proof. It was psychological anthropology that had to repeatedly reject the facts that initially seemed obvious. They had to reject them as those which cannot be proved (or even falsified). In the 80 -s of the XX century Gustav Jahoda, a psychological anthropologist, wrote: "There is a close relationship between psychology and anthropology, and we have something to give each other. Yet, the relationship does not have to call close and warm feelings; the feelings can be distant and cold ... The synthesis of anthropology and psychology is hardly needed. In the foreseeable future it is both unrealistic and undesirable. The differences can be instructive and even creative" (Jahoda, 1981: 266-267). For most psychological anthropologists, people of different cultures have different psychology, regardless of whether these differences are variants of universal psychological constitution or there are different psychological constitutions. For psychologists, psychology is a universal science which deduces general laws applicable to all people in the world. It does not recognize any phenomena beyond the scope of these universal laws.

In the 80 -s anthropologists began to look closely at psychology and namely at what is inside the scope of this discipline and whether psychology is wholly hostile towards psychological anthropology. It was not so. Cooperation between anthropologists and psychologists was in progress in the field of cross-cultural research. Yet, the main discovery was the following: the knowledge area of psychology that considered psychology as having both human physiology and culture in its basis, really existed. It was... Soviet psychology, represented by Lev Vygotsky, Alexei Leontiev, Alexander Luria and other scholars applying the "activity approach". Brought up on Marxism, the founders of the "activity approach" could not eliminate the social basis as a powerful means influencing the formation of human consciousness. Nowadays, the "activity approach" is widely known and popular in America, and many psychologists consider it to be a promising crisis measure for the discipline. However, a few decades ago American anthropologists' attitude towards the Soviet psychology was quite exotic. This resulted in the formation of cultural psychology, a new scientific discipline which is closely related to psychological anthropology.

There was another alternative for psychological anthropology. It is the so-called "cognitivist revolution" that has overwhelmed the world since the 70 -s. Originally, it did not play into the psychological anthropologists' hands but rather led to the displacement of psychological field of knowledge from cultural anthropology. According to cognitive sciences culture was meant to be consisting not of patterns of behavior but of information and knowledge encoded in the systems of symbols. "The main strength of this 
cognitivist revolution came from the intellectual wave that accompanied the development of modern computer. The scientific research of the peoples did not seem to be in need of conceptions that take into account such unobservable mental processes as thinking or feeling. This belief was rigidly connected with the development of computer programs that played chess and solved logic puzzles. If the computer can have a program, why cannot the peoples have it?" (D’Andrade, 1984: 88). Anthropologists gradually approached the analysis of the phenomena that were more and more psychological, yet "at the same time claiming that what is viewed by them is only "cultural" and has nothing to do with psychology. Even those anthropologists who study such phenomena as "self" or emotion often delimit "culture", the object of their research, from what they regard as a field of psychology" (Ewing, 1992: 251).

Nevertheless, the "cognitivist revolution" was a double-edged sword. Among the "cognitive sciences" there was also cognitive psychology, the development of which has long been associated with the idea of artificial intelligence. However, it took up such issues as perception, thought, and memory. Some authors came to the conclusion that these processes have a specific cultural determination. Cognitive anthropology was in the process of parallel development. As it was noted above, it branched off from psychological anthropology in the 50-s already and sought to study the mental structure of meanings. These two scientific disciplines improved their cooperation quite quickly. It was reasonable for psychological anthropologists to think about the way to express their ideas in the language of cognitive anthropology in order to be understood by cognitive psychologists. Thus, an overlapping area was formed between psychological and cognitive anthropology, and psychological anthropologists started making references to cultural models and schemas as mental complexes.

This happens when postmodernism in anthropology which, in fact, suggests abandoning scientific traditions in their usual understanding, gets ahead. The need for interdisciplinary cooperation made psychological anthropologists adopt more precise terms, a more rigorous language of scientific statements, i.e. to renounce all influences of postmodernism. Thus, from Theodore Schwartz's point of view, "if psychology turns to be unable to accept the results and assumptions of anthropological knowledge, both psychology and anthropology should be blamed. Although they both raise the question of human nature, there is a mutual alienation - inter-paradigmatic misunderstanding. The postmodern approach, which is currently widespread, is opposed to the desire to discover the world as it exists for others. It speaks of "construal", "penetration", "culture writing". Anthropology is concerned with "the creation of its own reality", "story telling". It has a keen self-awareness, literary and moral claims. It rejects science as scientism, sees the world as the word, believes in its own intuition and empathic understanding, and becomes irrational. This is not science; this is the contours of the religion of a new age... Our colleagues from other disciplines have no need to take our 'story tellings' seriously” (Schwartz, 1992: 324, 344). He suggests his conception of the experimental procedure models of culture as an approach acceptable to the psychologists. Roy D'Andrade, acting first on behalf of cognitive psychology, then on behalf of psychological anthropology, makes the conceptual framework of cognitive anthropology familiar and understandable for psychological anthropologists and creates the possibility to formulate the issues of psychological anthropology in the language of cognitive science. 
$* * *$

The problem of psychological anthropology at that time was not to turn into a different science under the influence of conjuncture but to maintain its basic principles, practice, and achievements. "Development of psychological anthropology has highlighted its problems and contradictions, the determination of niche, inside of which our sub-discipline is located, being not the least of them. In palmy days of the "Culture and Personality" school in the 40-s - 50-s Parsons' division of the world into the personality system, the cultural system provided a clear field of studies of culture and personality. The goal of these studies was the application of the personality theory to the analysis of the importance and motivational power of cultural forms for the personality. Theoretical niche of "Culture and Personality", however, became much less certain due to the development of many different areas in the social sciences. These changes seemed to mean the end of psychological anthropology. And it is a new approach only that can open the boundaries between psychological and other fields in anthropology" (White, Lutz, 1992: 3-4).

To open the boundaries, but not to change the nature of psychological anthropology, for many psychological anthropologists still believe deep in their mind that culture and psychology can and should be subject to the research taken as a whole. Yet, it is impossible to solve this problem on impulse the way the first representatives of this research field did. Each step needs to be deeply thought over theoretically. Moreover, it should be formulated in the language of terms, making it understandable for interdisciplinary communication. Meanwhile, psychological anthropology was as if partly distributed between cultural psychology and cognitive anthropology.
What is the contribution of psychological anthropology to cultural psychology and cognitive anthropology?

Cultural psychology comprises many approaches, but none of them covers the scope of this field of knowledge completely. Many of core ideas, that are associated with these approaches nowadays, arose within the bounds of various scientific disciplines. However, in the 90 -s quite a number of theoretical works characterize cultural psychology as an autonomous scientific area, which can be considered as an interdisciplinary approach but differs from the related fields of science. For example, Shweder explained its differences from general psychology, cross-cultural psychology, ethnic psychology and psychological anthropology (Shweder, 1991). However, these oppositions do not always seem to be indisputable. Psychological anthropology itself is not a comprehensive scientific school but a body of research approaches. Shweder disputes only some of the conceptual models inherent to a small number of psychological and anthropological approaches. If desired, his own theory can be considered a part of psychological anthropology with confidence. Jane Miller considers cultural psychology to be an interdisciplinary field, which has historical roots in anthropology, psychology and linguistics. These roots are often in those areas of these disciplines that were considered peripheral or even forgotten for a while. She sets out a number of key theoretical assumptions that are characteristic of cultural psychology: (1) attention to individual subjectivity; (2) non-reductionist idea of the relationship between culture, psychology and practice; (3) the idea of an integral unity of culture and psyche; (4) recognition of need for cultural diversity of psychology; (5) attention to the problems of communication and interaction (Miller, 1994: 142). So, all these assumptions are 
also the assumptions of classical psychological anthropology.

From the point of view of cultural psychologists, though it is impossible to deny the fundamental laws of the human psyche, connected with the perception of the objective world, the reality, however, can never be cognized in and on itself, regardless of the perspective in which the subject of cognition sees it. But this perspective largely depends on this subject's culture. Psychological universals are a necessary result of the similarity of cultural meanings and practices. Individuals are regarded not only as actively involved in the interpretation of meaning of experience, but as individuals collectively creating the "intentional" world. It is also recognized that individuals construe many realities, each having its own socio-historical grounds, but not a single reality independent of the observer. Cultural psychologists give greater importance to human activity than to traditional cognitive approaches and the approaches related to psychology of development. In its turn, individual psychology is treated as culturally constituted and potentially culturally variable.

A number of cultural psychologists (the most famous of these are Michael Cole and James Wertsch, the head of the so-called socio-cultural approach, considered as a part of cultural psychology) believe that the roots of cultural psychology are in the socio-historical approach associated with the names of Vygotsky, Luria and Leontiev. The assumption that psychological processes are culturally mediated, historically developing, contextually specific and arise from a human's practical activity and are rooted in it is central to this approach. In its other definition cultural psychology regards individuals as living in a culturally construed world. This approach is characteristic of Richard Shweder. Its other well-known representatives are Jerome Bruner and Jane Miller. According to the latter, "cultural psychology views cultural and psychological phenomena as interdependent and, moreover, inter-construed. It is assumed, that the individual is the carrier of culture, and his / her subjectivity is formed under the influence of cultural meanings and practices. This is why there cannot be a sharp dichotomy between psychology and culture. The view that individual subjectivity must be taken into account in understanding cultural meanings is also widely recognized. Cultural meanings, symbols and practices can be understood only from the point of view of the individual for whom they exist and have motivational force. Denying the postulate of the psychic unity, cultural psychology considers that the recognition of diverse cultural differences is essential for the explanation of individual psychological development. This proposition follows from recognition of the fact that psychological processes are culturally constituted and, therefore, vary according to the differences in cultural meanings and practices. Cultural psychology does not deny the possibility of universal psychological processes but believes that the latter are caused by a certain similarity in cultural meanings and practices. The importance of biological processes is not denied, but they are viewed as culturally dependent" (Miller, 1994: 144-145).

Individuals are viewed not only as actively involved in the interpretation of meaning of experience, but as individuals collectively creating the intentional ("construed") worlds, a large number of socio-historically grounded realities, but not a single reality independent of the observer. Cultural symbols and practices can be understood only "in terms" of the individual, for whom there exist meanings and for whom they have motivational force. Psychological processes can vary within the range of meanings and practices allowed for this culture. Thus, culture is fully consistent with psychological 
anthropology and is, in fact, its theoretical ground.

During the same years there was a transformation in cognitive sciences, which led in particular to a rapid development of cognitive anthropology. The subject of its research gradually changed. If originally, in the 60-70-s, cognitive anthropologists analyzed the vocabulary and semantics of the language, considering them to be a key to cognitive organization of knowledge about culture, then in the 80-s the emphasis extended to the study of cognitive processes that result in cultural learning, distribution of cultural knowledge, interrelation of cultural meanings with the political order, but also of conflict nature of cultural messages, the process by which cultural meanings receive their motivational force. Then, in the $90-\mathrm{s}$, the cognitivists turn to the study of the impact of culture on individual subjectivity and behavior, that is get closer to cultural psychology and psychological anthropology. "The theorists mainly focus on discourse, but not on the vocabulary, cultural schemas, or semantics of the language. The theoretical debates develop around how the collectively interpreted practice forms the basis for the individuals' thinking” (Holland, 1992: 68). Cognitive anthropologists focus on how the systems of cultural knowledge are formed by a human's cognitive mechanisms, how the process of its transmission takes place, how "cultural knowledge settles into an organized state so that it "corresponds" to the abilities and limitations of human mind" (D'Andrade, 1981: 182). The data about certain societies are viewed in an intercultural perspective. Variability in cultural knowledge occupies a central position in cognitive anthropological studies of how the difference in individual patterns is organized into cultural systems, and how individual variability gives rise to changes in common cultural systems (Romney, Weller, Batchelder, 1986).

Culture in cognitive anthropology is regarded, on the one hand, as a part of the environment, and, on the other hand, as a mechanism for organizing our knowledge. Through culturally organized knowledge we receive information about the outside world. Cognition, according to Michael Cole, can be described as a system of interaction between our consciousness and the outside world (Cole, 2003). Symbolic cultural system provides for adaptation to the environment (Simon, 1981: 27).

Modern cognitive anthropology establishes the connection between the cultural system of meanings and psychological processes. So, Roy D'Andrade argues that a meaningful system includes an affective component as well (D'Andrade, 1984: 91). Each symbol causes a lot of affectively bound associations within meaningful systems. D'Andrade concludes that the "meanings" are in human psychology. Every aspect of meaningful systems requires the involvement of psychological processes, the involvement often being very considerable. Representation is possible only due to the fact that the "symbols" activate the whole set of psychological processes. Representative, constructive, directive and evocative functions are due to a specific organization of human brain, biological and psychological potential of which is stimulated by culturally "meaningful systems". Emotion is a constituent part of cognition.

\section{$* * *$}

A characteristic feature of psychological anthropology of the last twenty years of the XX century is in integration of conceptual terms of cognitive anthropology. It is the cognitivist approach that helped to overcome anti- 
psychologism of the symbolic approach while maintaining all the constructive the latter had. The discussion between cognitive anthropology and symbolic anthropology was mainly about the most fundamental issue, the issue being whether cultural systems exist inside or outside human mind. For symbolic anthropology they are outside a human. Cognitive anthropology studies human mind and obviously assumes that culture is concentrated inside a human. Psychological anthropologists, in their turn, were anxious to prove that the internal and external systems of meanings are interrelated. Moreover, this relation is such that it leads to a human's motivational attitudes and thus provokes human activity.

$* * *$

It is worth analyzing how the leading psychological anthropologists, closely linked to cognitive anthropology and cultural psychology, stated the main issues of their research.

Jeffrey White aimed to show how human subjectivity, human emotions form a social reality, in particular, how they form culture through discourse. The focus of his interest is how cognition takes on a motivational aspect while becoming a psychological phenomenon and gets expressed in social behavior. Cultural "conceptual" scheme is regarded by White as a possible source of our actions. As a mental complex it corresponds to the cultural scenario. White puts the question of how our ideas shape the cultural script. White does not regard the question of complex consideration of culture and personality, these being two systems with respect to which psychological anthropologists need to prove that they interact with each other. According to White, it is necessary to prove not the correlation of both systems as a whole but their components (White, 1992).
Theodore Schwartzused the "experimentaland-procedural" constructs. These are cognitions linked with emotional and motivational components and are like building blocks of culture. Schwartz explains culture through psychological categories. In his opinion, symbols and cultural meanings root from psychology. According to Schwartz, psychological anthropology perceives all the concepts of symbolic anthropology, giving them psychological interpretation. Schwartz develops the "experimental-and-procedural" distributive model of culture, referring not so much to the individual interpretation of culture, but to the hierarchy of cultural constructs, some of which constitute the core of culture and are inherent to everybody, others are inherent only to these or those intracultural groups formed on the basis of common practice and able to change their boundaries, and the rest are characteristics of a particular individual. Schwartz refers to culture as a dynamic structure, interaction of intracultural groups, their conflicts being sources of changes in cultural structure (Schwartz, 1978; 1989; 1992).

Melford Spiro takes the symbolist conception of culture but shows that this anti-psychological conception, if being carried out consistently (when not only the emotional-motivational sphere but also the sphere of thinking is considered as an area of the psychological), inexorably leads us to the fact that while studying culture we must study individuals who are the carriers of this culture. Spiro demonstrates how cultural values, interpreted in the minds of the carriers of culture, arouse thoughts, feelings and desire to act. A personality also affects the culture, using it as an adaptive mechanism. If any cultural features cease to be subjectively meaningful to a person, they die. If some human experience is of public interest, it gradually acquires the cultural meaning and becomes a cultural phenomenon. Spiro considers culture as a cognitive system. However, 
in his system cognition, understood as a process, is regarded as a psychological phenomenon. Becoming an object of an individual's attention, every cultural meaning expands and turns into a range of meanings. Spiro develops a system of relations between cultural and personal meanings (Spiro, 1984).

Robert LeVine linked his teaching about culture with symbolic anthropology. He does not get into argument with it but complements it. He agrees to consider cultural and psychological phenomena separately but under the condition that their close relationship is recognized. According to LeVine, personality is determined by cultural norms, institutions and meanings outside and by personal disposition and personal psychological features inside. Herewith the personal disposition itself is culturally based, unconscious and different for different cultures (LeVine, 1974; 1984).

Michael Cole raised the question of the relationship between internal and external cultural meanings. In his interpretation these meanings are not just inextricably related to each other but are actually merged together through the mediating mechanism of artifacts. Psychology and culture are inseparably linked, culture is one of the most important components under the influence of which human psychology is formed. "Cultural schema" and "script" are interpreted by Cole as artifacts characteristic of human psychology. He comes to the conclusion that people are born with predisposition to the perception of culture. At his time Noam Chomsky came to the conclusion about a human's innate predisposition to language acquisition (Cole, 1995a; 1995b; 1997).

Richard Schweder considered culture and personality as two sides of the same coin. Personality is formed under the direct influence of culture; ideas, thinking, logic inherent to a man are culturally determined. It is meaningless to study culture separately from psychology and to study psychology separately from culture. Our vision of the world is determined by culture which we grew up and were socialized in. Culture determines our actions, behaviour, and communication with other people. Schweder introduces the concept of cultural framework that determines the measure of variability of any given culture. He resorts to the concept of meaningful schema, defining it in connection with the concepts a person thinks with. Schweder accepts the doctrine of cultural meanings developed in symbolic anthropology. Yet, he does not only want to consider them as an external entity but also contrasts the external meanings with the internal ones. The meanings exist insofar as people understand them and operate with them. The culture changes together with human experience. Culture also depends on the individual the same way the individual depends on culture. From Shweder's point of view, there is no reality that would be independent from our participation in it (Shweder, 1984; 1990; 1991).

Roy D'Andrade established a link between culturally meaningful systems formed in the individual's mind, and external cultural phenomena (which he proposes to term as symbols not to confuse them with meanings which are mental phenomena). As a source of culture, meanings are integrally linked to human psychology due to the fact that besides representative functions they also have creative, directive and evocative ones. D'Andrade demonstrates how individuals build their external world in the process of communication (exchange of messages) on the basis of meaningful systems. D'Andrade shows the relationship of meaningful systems with culture as a system, personality as a system, social system and the "flow of material", which is not yet included in the meaningful cultural systems. He considers culture as a dynamic structure associated with human 
experience and changing along with the change of this experience, the change being parallel to the situation when some of the meaningful systems lose their relevance and cease to be the subject of interpersonal communication and other meaningful systems develop and take the place of the dying ones. Humans imagine the world as if in an "adapted" form, they adapt to it psychologically. Therefore, the cultural worlds of different peoples are different. Cognitive scheme links culture and human psychology: getting into the psyche of the humans in the process of their socialization and enculturation, cognitive schema directs their actions. Cognitive schema is an unconscious means of interpretation of the events. It forces the humans to see the outside world at a certain, culturallydetermined perspective and act in accordance with their culturally-determined interpretation of the world events. Cognitive schemas generate one another and entangle the world like a web, so that the whole world we perceive is sifted through the network of culturally-established cognitive schemas (D’Andrade, 1981; 1984; 1992a; 1992b; 1995).
The research fields of psychological anthropology, cognitive anthropology and cultural psychology as an area that can be collectively defined as psychological cultural studies are divided so weakly that we cannot say whether each one will develop into a quite independent discipline (though tightly linked with the other two) with its own goals, objectives and methods, or they will eventually merge into a single discipline. Today the boundary lines between them are difficult to draw. Each of these three disciplines contains approximately half of the studies which can be realistically attributed to another discipline or even to three of them at once. The other half, in its turn, embraces a half of the studies that can be assigned to other areas of knowledge, such as cross-cultural studies, cognitive psychology, developmental psychology, and psycholinguistics. Only a remaining part of each of these disciplines will be original. Thus, it is psycho-culturology as a new field of knowledge that could integrate all of them.

\section{References}

Bock, Ph. (1994). Handbook of Psychological Anthropology. Westport, Connecticut-London, Greenwood Press.

Cole, M. (1995a). Kul'turnye mekhanizmy razvitiia [Cultural Mechanisms of Development], In Voprosy Psikhologii [Psychology Issues], 3.

Cole, M. (1995b). Socio-Cultural-Historical Psychology: Some General Remarks and a Proposal for a New Kind of Cultural-Genetic Methodology, In Wertsch J. (ed.) Sociocultural Studies of Mind. Cambridge University Press.

Cole, M. (1997). Kul'turno-istoricheskaia psikhologiia [Cultural and Historical Psychology]. Moscow, Kogito-tsentr.

Cole, M. (2003). Culture and Cognitive Science. Talk Presented to the Cognitive Science Program, U.C. Santa Barbara. Available at: http://www.researchgate.net/publication/278406542_Culture_and Cognitive_Science (accessed 22 September 2015).

D'Andrade, R. (1981). The Culture Part of Cognition, In Cognitive Science, 5.

D’Andrade, R. (1984). Cultural Meaning Systems. In Shweder, R., LeVine, R. (eds.) Cultural Theory. Essays on Mind, Self, and Emotion. Cambridge, L., NY., New Rochelle, Melbourne, Sydney, Cambridge University Press. 
D’Andrade, R. (1992a). Cognitive Anthropology. In Schwartz, Th., White, G., Lutz C. (eds.). New Direction in Psychological Anthropology. Cambridge, Cambridge University Press.

D’Andrade, R. (1992b). Shemas and Motivation. In D'Andrade, R., Strauss, C. (eds). Human Motive and Culture Models. Cambridge, Cambridge University Press.

D’Andrade, R. (1995). The Development of Cognitive Anthropology. Cambridge, Cambridge University Press.

Ewing, K. (1992). Is Psychoanalis Relevant for Anthropology? In Schwartz, Th., White, G., Lutz, C. (eds.) New Direction in Psychological Anthropology. Cambridge, Cambridge University Press.

Geertz, C. (1984). "From the Native's Point of View". On the Nature of Anthropological Understanding. In Shweder, R., LeVine, R. (eds.) Cultural Theory. Essays on Mind, Self, and Emotion. Cambridge, L., NY., New Rochelle, Melbourne, Sydney, Cambridge University Press.

Holland, D. (1992). The Woman Who Climbed Up the House: Some Limitations of Schema Theory. In: Schwartz, Th., White, G., Lutz, C. (eds.) New Direction in Psychological Anthropology. Cambridge, Cambridge University Press.

Jahoda, G. (1981). Psychology and Anthropology. A Psychological Perspective. L., NY, etc., Academic Press.

LeVine, R. (1974). Culture, Behavior and Personality. An Introduction to the Comparative Study of Psychosotial Adaptation. Chicago, Aldine Publishing Company.

LeVine, R. (1984). Properties of Culture. An Ethnographic View. In Shweder, R., LeVine. R. (eds.) Cultural Theory. Essays on Mind, Self, and Emotion. Cambridge, L., NY., New Rochelle, Melbourne, Sydney, Cambridge University Press.

Miller, J. (1994). Cultural Psychology: Briding Diciplinary Boundaries in Understanding the Cultural Grounding of Self. In Bock, Ph. (ed.) Handbook of Psychological Anthropology. Westport, Connecticut-London, Greenwood Press.

Romney, A., Weller, S., Batchelder, W. (1986). Culture as Consensus: A Theory of Culture and Informant Accuracy, In American Anthropologist, 88.

Schwartz, Th. (1978). Where is the Culture? In Spindler, G (ed.) The Making of Psychological Anthropology. Berkeley, University of California Press.

Schwartz, Th. (1989). The Structure of National Cultures. In Funke, P. (ed.) Understanding of USA: A Cross-Cultural Perspective. Tubengen, Gunter Narr Verlal.

Schwartz, Th. (1992). Anthropology and Psychology. In Schwartz, Th., White, G., Lutz, C. (eds.) New Direction in Psychological Anthropology. Cambridge, Cambridge University Press.

Schwartz, Th., White, G., Lutz, C. (1992). New Direction in Psychological Anthropology. Cambridge, Cambridge University Press.

Simon, H. (1981). Sciences of the Artificial. Cambridge, MA, MIT Press.

Shweder, R. (1990). Cultural Psychology - What is It? In: Stigler, J., Shweder, R., Herdt, G. (eds.) Cultural Psychology: Essays on Comparative Human Development. New York, Cambridge University Press.

Shweder, R. (1991). Thinking through Cultures. Cambridge (Mass.), London (England), Harvard University Press.

Shweder, R., LeVine, R. (1984). Cultural Theory. Essays on Mind, Self, and Emotion. Cambridge, L., NY., New Rochelle, Melbourne, Sydney, Cambridge University Press.

$$
-981-
$$


Shweder, R. (1984). Anthropology's Romantic Rebellion against the Enlightenment, or There's More to Thinking than Reason and Evidence. In Shweder, R., LeVine, R. (eds.) Cultural Theory. Essays on Mind, Self, and Emotion. Cambridge, L., NY., New Rochelle, Melbourne, Sydney, Cambridge University Press.

Spindler, G. (1978). The Making of Psychological Anthropology. Berkeley, University of California Press.

Spiro, M. (1984). Some Reflections on Cultural Determinism and Relativism with Special Reference to Emotion and Reason. In Shweder, R., LeVine, R. (eds.) Cultural Theory. Essays on Mind, Self, and Emotion. Cambridge, L., NY., New Rochelle, Melbourne, Sydney, Cambridge University Press.

White, G. (1992). Ethnopsychology. In Schwartz, Th., White, G., Lutz, C. (eds.). New Direction in Psychological Anthropology. Cambridge, Cambridge University Press.

White, G., Lutz, C. (1992). Introduction. In Schwartz, Th., White, G., Lutz, C. (eds.). New Direction in Psychological Anthropology. Cambridge, Cambridge University Press.

\title{
От культурной антропологии \\ к психологической культурологии: \\ новое осмысление взаимосвязи \\ культурного и психологического
}

\author{
С.В. Лурье \\ Социологический институт РАН \\ Россия, 190005, Санкт-Петербург, \\ ул. 7-я Красноармейская, 25/14
}

\begin{abstract}
Статья посвящена истории возрождения психологической антропологии в восьмидесятыедевяностые годы ХХ века после периода ее упадка. В шестидесятые годы ХХ века психологическая антропология уже не могла рассматриваться как полноправная часть культурной антропологии. Под вопрос была поставлена сама взаимосвязь культурного и психологического - ее следовало переосмыслить. Новое понимание этой взаимосвязи дали когнитивная антропология, возникшая в результате развития когнитивных наук, и культурная психология, отталкивавшаяся от психологии Льва Выготского и других представителей «деятельностного подхода». В статье рассматриваются различные аспекты взаимовлияния когнитивной антропологии, культурной психологии и психологической антропологии, новые вопросы, которые стоят сегодня перед психологическими антропологами.
\end{abstract}

Ключевые слова: психологическая антропология, когнитивная антропология, культурная психология, когнитивные науки, системы культурных значений, функция культурных значений, когниции, эмоцчии.

Научная специильность: 24.00.01 - теория и история культуры. 